\title{
Military leadership: A systematic literature review of current research
}

\author{
Mohammad Nazri and Mohamad Rudi \\ Department of Business Policy \& Strategy, Faculty of Business \& Accountancy \\ University of Malaya, Malaysia
}

\begin{abstract}
Although leadership is generally a complex concept, its application is crucial, especially for military organisations. Many have believed that leadership theory begins with research on military leaders. However, empirical studies on military leadership in recent years have been scarce. This study set out to analyse the recent extant literature on military leadership by applying a systematic literature review methodology. Guided by the PRISMA technique, two databases, Scopus and Web of Science, were employed, resulting in 16 related empirical studies. Further analysis of the studies revealed four significant themes: (1) leader attributes and traits; (2) leadership development; (3) adverse situations and environments, and (4) policy, guiding principles, and standards. The themes are conceptualised into a proposed military leadership framework, and several recommendations are reconciled based on the proposed framework. Leader traits and attributes remain a potential area for future research on military leadership coherent with other themes. The review also indicates that a number of further research directions should to be considered as the extant military leadership studies were only prevalent within the USA and several European countries as settings, mixed methodology is still an underutilised approach, and high ranking military leaders as well as gender studies were found to be other promising future research directions.
\end{abstract}

Key words: Military Leadership, Attributes and Traits, Leadership Development, Adverse Situations and Environments, Military Policy. Systematic Literature Review

\section{INTRODUCTION}

Leadership studies are found to vary by domains, paradigms and variables. These variations are found when the subject of leadership is the central to discussion. Most, if not all, current leadership researchers tend to be in agreement with earlier prominent leadership scholars that leadership changes when the setting changes [1][2]. Accordingly, leadership definitions have been asserted to be vigorous and correspondingly altered according to situations and environments [3]. While leadership has always been a complex notion to digest, organisations have never hesitated to invest in the leadership development of their employees [4]. Likewise, leadership is always a crucial factor in the military. In fact, leadership as an important concept was believed to be inspired from military leaders [5]. Factually, throughout world history, leadership qualities shown by military leaders have been significantly admired and well-respected.
Consequently, many military leaders have been recorded as the most influential figures in world history [6][7].

Military leaders, similarly to leaders of other organisations, make important judgements, often at a critical moments. While a successful Chief Executive Officer may make billions in company revenues from a business deal, a successful military general influences the future of a nation on the battlefield. However, in contrast to other leaders, wrong decisions made by military leaders could cause the deaths of hundreds of people who are not necessarily combatants, but innocents [8]. Blunders made by military leaders have proven to be more catastrophic compared to leaders of other fields, as substantiated from world war history and several world security conflicts [9]. Manifestly, successes and failures of military leaders and military leadership have continually been the models and 
exemplars on which high standards have always been based.

In recent years, military leaders have been faced with the dynamism of challenging situations. The fluidity of current geopolitics and geostrategic environments, rapid advancement of warfare technologies and the diversity of today's defence and security threats are some of the major factors that have certainly further enhanced the complexity of military leadership [10]. Just as the general organisational leadership literature is quite diverse [11], this is so for the literature on military leadership. Taking these topics as initiative, this study undertakes a systematic review of military leadership literature with the aim of identifying current research interests and their dynamism, consequently suggesting pertinent issues for future research endeavours.

\section{METHODOLOGY}

\section{PRISMA}

Literature review is an essential process in any academic research. In addition to ascertaining and enriching prior knowledge, literature review updates and enhances knowledge from extant studies. Nevertheless, the effectiveness and rigorousness of a literature review is very much dependent on its systematic and procedural analysis [12]. Hence, this review was guided and consistently complied with a Preferred Reporting Items for Systematic Reviews and Meta-Analyses (PRISMA) procedure.

PRISMA is recognised as a rigorous method of conducting literature review. Several distinctive advantages offered by PRISMA are, firstly, it guides researchers in the clear definition of research questions; secondly, it guides researchers to recognise the inclusion and exclusion criteria for literature; and thirdly, it provides researchers with guidelines to precisely examine large databases within a reasonable timeframe [13].

\section{Resources}

The use of two databases, such as Web of Science (WoS) and Scopus, would augment academic search as both databases are rich with information required by researchers [14]. Furthermore, both databases have strong coverage of academic articles that in most cases complement each other in their content, method and approaches. Additionally, WoS has long been admirably acknowledged in the academic field as one of the most reliable sources for research discovery and analytics databases.
In its most recent version, WoS stores over 100 years' worth of content and seamlessly provides access to multiple other databases. Hence, in-depth exploration of specialised or multiple academic disciplines and sub-fields could be comfortably accomplished. With the same reputation, Scopus, as another well-established database, encompasses more than 36,000 titles from more than 11,000 publishers of high quality, multiple-subject, peerreviewed journals. Hence, these two eminent electronic research databases were used for the literature search in this study.

\section{Eligibility and Exclusion Criteria}

The review exercised numerous criteria to ensure that only relevant studies were systematically selected. The inclusion criteria are highlighted as follows: (1) only articles published from January 2008 to December 2018 were selected, an adequate timeframe representative of recent and contemporary research; (2) only empirical research journal articles were selected of which review articles, book chapters, book series and conference proceedings were disqualified; (3) only English language publications were accepted; and lastly, (4) the main attention of this review was military leadership, and the geographical range of studies was purposely left open to any territories, countries and continents. This would open up the opportunity to cover expansive military leadership knowledge from across the globe as the fundamental issues of the subject are always closely similar and comparable. The inclusion and exclusion criteria were thus set and summarised as shown in Table 1.

\section{Table 1}

Inclusion and exclusion criteria

\begin{tabular}{lll}
\hline Criterion & Eligibility & Exclusion \\
\hline $\begin{array}{l}\text { Type of } \\
\text { Literature }\end{array}$ & $\begin{array}{l}\text { Journal/Research } \\
\text { articles }\end{array}$ & $\begin{array}{l}\text { Journals (Review), } \\
\text { book series, book } \\
\text { chapters, conference } \\
\text { proceedings }\end{array}$ \\
$\begin{array}{l}\text { Language } \\
\text { Timeline }\end{array}$ & $\begin{array}{l}\text { English } 2008-\text { Dec 2018 } \\
\text { Jan-English }\end{array}$ \\
\hline
\end{tabular}

SLR Process

The review was performed in March 2019. Four major steps were involved in the review process. The first step included the identification of keywords on military leadership, which are represented as the search strings shown in Table 2. 
Table 2

Search string used

\begin{tabular}{lll}
\hline Databases & Keywords & \\
\hline Scopus & TITLE-ABS-KEY & ("military \\
& leadership" OR "armed forces \\
& leadership" OR "Army leadership" OR \\
& "Naval leadership" OR "Air Force \\
& leadership" OR "Defence Force \\
& leadership") & \\
Web of Science & TOPIC:("military leadership*" OR \\
& "armed forces leadership*" OR "Army \\
& leadership*" OR "Naval leadership*" \\
& OR "Air Force leadership*" OR \\
& "Defence Force leadership*") \\
\hline
\end{tabular}

The removal of 16 duplicate articles resulted in 111 remaining articles. The subsequently conducted screening process was for eligibility, and 77 more articles were excluded due to several criteria regarding their identification as book series and chapters, conference proceedings and non-English publications. Another 18 articles were later discarded based on not having a focus on military leadership and no empirical data recorded. Finally, only sixteen articles met all criteria of the systematic review. The detailed screening process is illustrated in the PRISMA flow diagram shown at Figure 1.

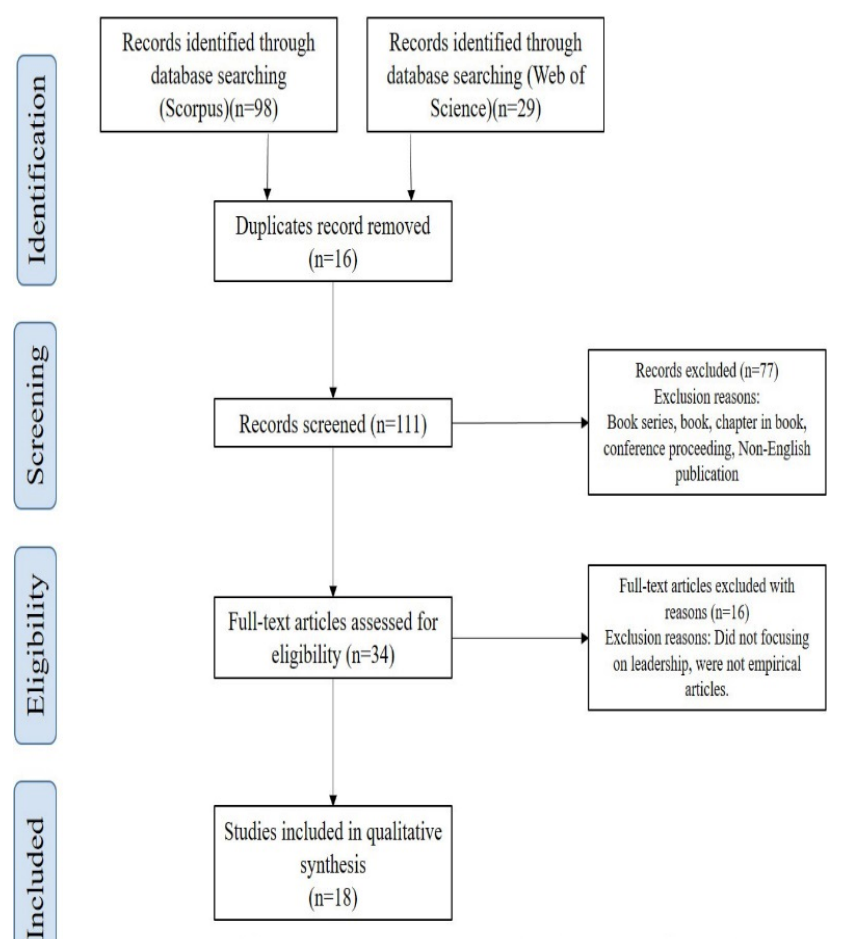

A flow diagram explaining the PRISMA application to the synthesis of published studies into Military Leadership 2008 to 2018

Figure 1. Flow diagram of the study

\section{Data Mining and Analysis}

The final set of 16 articles went through another evaluation and synthesis process. The relevant data were obtained by first reading the abstracts and then arriving at an in-depth understanding of the full articles. In the first stage of the process, the review summarised all the articles based on research aim, research design, sample size, type of respondent, data collection method, analysis technique and key findings. The detailed features and characteristics of each article are presented in Appendix 1.

The second stage was identifying appropriate subthemes, and then the process of recognising the most appropriate themes was performed. The process employed qualitative methodology, specifically utilising content and thematic analysis techniques. The use of these techniques managed to establish logical and applicable military leadership themes from all the final articles.

\section{RESULTS}

The results offered an inclusive, wide-ranging analysis of military leadership studies and presented several important sub-topics to reveal detailed components of the review. This begins with the review characteristics, results from the thematic analysis and the description of each theme.

\section{Study Characteristics}

A total of nine studies concentrated on United States military leadership settings. Two studies were from Sweden and Norway, one each from Australia and the UK, and one represented a combined effort from Sweden and Norway.

Generally, research on military leadership has no consistent pattern for the last ten years beginning in 2008. Nevertheless, within the last ten years since 2008, the year 2014 was found to have the highest number of military leadership research articles with five having been published. The publications show a declining pattern in 2015 and 2016 with three and one article, respectively. The period of 2017 and 2018 showed a slight increment of two articles each for 2017 and 2018.

In another aspect of the review, qualitative and quantitative approaches were found to be the preferred techniques in military leadership studies over the last ten years. Mixed mode was the least used approach chosen by researchers in this field with only one representative 
APPENDIX 1

\section{DETAILED FEATURES AND CHARACTERISTICS OF EACH ARTICLE}

\begin{tabular}{|c|c|c|c|c|c|}
\hline Articles & $\begin{array}{l}\text { Country } \\
\text { Settings }\end{array}$ & $\begin{array}{l}\text { Respondent } \\
\text { Sample Size }\end{array}$ & Instrument & Design and Method & Findings \\
\hline$[15]$ & USA & $\begin{array}{l}251 \text { United States Air Force } \\
\text { Academy cadets and } 34 \text { United } \\
\text { States Air Force officers. }\end{array}$ & $\begin{array}{l}\text { Leadership self-assessment measure; a } \\
\text { learning goals measure (adapted from Elliot } \\
\& \text { Church, 1997), and a self-esteem } \\
\text { measure (Rosenberg, 1965) }\end{array}$ & Quantitative/ Correlation & $\begin{array}{l}\text { (1) Military leaders always overestimate their leadership quality } \\
\text { and abilities. } \\
\text { (2) Self-ratings are weighted stronger that other ratings. }\end{array}$ \\
\hline$[16]$ & Sweden & $\begin{array}{l}16 \text { Swedish officers and soldiers } \\
\text { with experience from international } \\
\text { peacekeeping operations } \\
\text { (Qualitative) } \\
102 \text { respondents from the Swedish } \\
\text { Armed Forces who had recently } \\
\text { served in Afghanistan } \\
\text { (Quantitative) }\end{array}$ & $\begin{array}{l}\text { Qualitative: Interview; } \\
\text { Quantitative: Openness; Emotional } \\
\text { stability; Inner moral compass; } \\
\text { Intelligence; Will/energy; Prepared/ } \\
\text { trained; Competent; Can "read the } \\
\text { situation" }\end{array}$ & $\begin{array}{l}\text { Mixed/ } \\
\text { Qualitative: Grounded Theory; } \\
\text { Quantitative: Regression and correlation }\end{array}$ & $\begin{array}{l}\text { Study } 1 \text { suggests that two balancing acts are the crucial features of } \\
\text { adaptive leadership in such situations. One is how subordinates treat } \\
\text { structure/following rules against using their own initiatives or } \\
\text { freedom of action. The other concerns the balance between } \\
\text { individual decision making versus group feedback. Both are } \\
\text { influenced by availability of time, resulting in a } \\
\text { favourable/unfavourable outcome. The hypotheses from Study } 1 \\
\text { were partially established in Study } 2 \text {. }\end{array}$ \\
\hline [17] & Sweden & $\begin{array}{l}12 \text { interviews (two of which were } \\
\text { with women). The informants had } \\
\text { wide experience in a number of } \\
\text { leadership positions as well as } \\
\text { participation in international } \\
\text { operations, ranks from Colonel to } \\
\text { Brigadier General and they } \\
\text { represented army and naval units, } \\
\text { the Armed Forces Headquarters and } \\
\text { Swedish Defence University. }\end{array}$ & Interview & Qualitative/ Grounded Theory & $\begin{array}{l}\text { Establishing and balancing organisational commitment is explained } \\
\text { as job satisfaction of strategic-level military leaders. This is } \\
\text { obviously shown by the theoretical model established from the } \\
\text { qualitative analysis. The results exhibit a continuous process of } \\
\text { developing, managing and recreating a "sense of oneness" between } \\
\text { the leaders and the organisation. Two predominant sets are } \\
\text { developed by establishing and balancing organisational } \\
\text { commitment: maintaining the organisational impression and } \\
\text { reacting to organisational greediness. }\end{array}$ \\
\hline [4] & USA & $\begin{array}{l}\text { A purposive sample of } 10 \text { lower } \\
\text { enlisted Army veterans completed a } \\
\text { pre-military r leadership } \\
\text { autobiography }\end{array}$ & Interview & $\begin{array}{l}\text { Qualitative/ Phenomenological study (a } \\
\text { face-to-face interview) }\end{array}$ & $\begin{array}{l}\text { Four primary themes emerged: (a) consistent first Army } \\
\text { experiences, (b) observed leadership, (c) performing is essential, } \\
\text { and (d) we are all leaders despite not understanding the process. }\end{array}$ \\
\hline [18] & USA & $\begin{array}{l}\text { Set } 1.672 \text { participants who were } \\
\text { performing in } 70 \text { teams as part of } \\
\text { the ODP (Officer Development } \\
\text { Program) }\end{array}$ & $\begin{array}{l}\text { Control Variables: Source of Entry and } \\
\text { Strategy Knowledge. } \\
\text { Explanatory Variables: Knowledge and } \\
\text { Action } \\
\text { Interaction Term: Knowledge X Action }\end{array}$ & $\begin{array}{l}\text { Quantitative/ Testing the hypothesized } \\
\text { interaction with moderated path analysis } \\
\text { of data from two field studies on team- } \\
\text { based trainees in a military leadership- } \\
\text { development program. } \\
\text { (Correlation \& Regression Analysis) }\end{array}$ & $\begin{array}{l}\text { The findings indicate that an exceptional leader among peers mus } \\
\text { possess both pertinent expertise and a propensity to use } \\
\text { effectively. Both attributes are interdependent rather than } \\
\text { independent. }\end{array}$ \\
\hline
\end{tabular}




\begin{tabular}{|c|c|c|c|c|}
\hline Articles & $\begin{array}{l}\text { Country } \\
\text { Settings }\end{array}$ & $\begin{array}{l}\text { Respondent } \\
\text { Sample Size }\end{array}$ & Instrument & Design and Method \\
\hline & & $\begin{array}{l}\text { Set } 2.472 \text { additional participants } \\
\text { from the same program but from a } \\
\text { different time }\end{array}$ & & \\
\hline [19] & Norway & $\begin{array}{l}174 \text { crew members of Norwegian } \\
\text { state-of-the-art, Nansen-class } \\
\text { frigates }\end{array}$ & $\begin{array}{l}\text { Leadership behavior was measured using } \\
\text { the Systematizing Person Group Relation } \\
\text { (SPGR) instrument. The SPGR } \\
\text { questionnaire consists of } 24 \text { items that are } \\
\text { rated on a 3-point scale (rarely, sometimes, } \\
\text { often). }\end{array}$ & 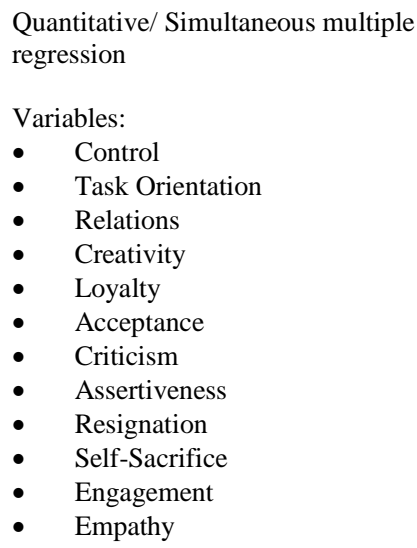 \\
\hline
\end{tabular}

The result indicates that there is a negative relationship where the greater the task uncertainty, the more deviation behaviour by the preferred leader from mission command. The most importan predictor was perceived lack of information.

\section{Qualitative/ Case Study Inquiry}

\section{Qualitative/ Phenomenology -} epistemological philosophy that emphasizes one's lifeworld, or "lived $\begin{aligned} & \text { experience," in the structuring of } \\ & \text { consciousness }\end{aligned}$
and subjectivity/ Triangulation. It is argued that Grant's capacities for strategic thinking, clear expression, and courageous inperturbability enabled him to lead the Union to victory in the Civil War, achieve notable but overlooked successes

The phenomenon is described by seven themes: mutual influence, leadership emergence, dangerous dynamism, and distributed knowledge, skills, and abilities. The findings precisely suggest that mutual influence and leadership emergence to share leadership and achieve high performance were used by military teams in dangerous situations. Moreover, the relationship between shared leadership and performance for military teams in dangerous settings may be moderated by dangerous dynamism and distributed knowledge, skills, and abilities.

The study positions two leadership practices, which are competencies and contextual construct. The result indicates the explanatory potential of embodiment and an associated effect on the process of leadership
The study managed to reveal fluidity of people and material hybridized network did make leadership matter. As configurations 
Nazri \& Rudi / International Journal of Business and Management, 3(2) 2019, Pages: 01-15

\begin{tabular}{|c|c|c|}
\hline Articles & $\begin{array}{l}\text { Country } \\
\text { Settings }\end{array}$ & $\begin{array}{l}\text { Respondent } \\
\text { Sample Size }\end{array}$ \\
\hline & & $\begin{array}{l}\text { of personnel of a Royal Navy base } \\
\text { (HMS Naval Base). The shore-based } \\
\text { naval establishment is home to a } \\
\text { major leadership-training base for } \\
\text { the Royal Navy where ratings } \\
\text { (enlisted personnel below warrant } \\
\text { officer rank) and non-commissioned } \\
\text { officers (NCOs) receive leadership } \\
\text { training prior to promotion to the } \\
\text { next rank. }\end{array}$ \\
\hline
\end{tabular}

[24]

USA 102 leadership events drawn from the career of an eminent leader, General George C. Marshall (an individual that played an importa role in shaping the modern U.S. Army)

USA West Point classes of 2005 and 2006 Officer Cadets

They were later again participants in the same study after becoming officers.

Effective communication

- Developed network

- Leader skills and abilities

Collectivistic actio

Dispositional Resilience Scale - DRS-15 (v.1) to measure hardiness, Whole Candidate Score (WCS) and Scholastic Aptitude Test (SAT) score

Online survey

Exploratory study framed within a synthesis of evolutionary psychological and sociological theory. Respondents describe tactics to achieve levels of

operational competency, respect, trust, and success in the Marine Corps.

Design and Method

Findings

of actants evolve, these affordances are altered, and the blackboxing processes hiding the material actants' co-generating leadership effects are uncovered. A detailed explication of the politicized affordances within actor networks contributes to knowledge about how hybridized relationships co-enable possibilities for action that bring to life, reinforce and call into question the human-centred, gendered, colonialist web of assumptions and practices through which Royal Naval personnel understand and enct les through Indeen 'bership. Indeed, by 'blackboxing' the roles of matial actants in the production, gendering and undoing of leadership effects, leadership studies scholars risk perpetuating individualistic, masculinist apt
heroic assumptions about how leadership effects are generated.

The results of this study using historiometric analysis indicated that

Quantitative/ Historiometric studies/ Correlation and regression

Quantitative/ Correlation and regression

Results indicate that while the traditional measure WCS predicts leader performance in the stable, highly regulated environment of West Point, it does not predict leader adaptability and performance in the uncertain environment of real-world operations. In contrast psychological hardiness (commitment and control facets) measure as academy freshmen predicts leader adaptability in officer measured 7 years later. Psychological hardiness appears to be promising factor in promoting the development of adaptability.

There were few differences between officers of different military background regarding the meaning, relevance, and consequences of the military model. However, significantly different ratings given to empowerment of those at lowest levels, to the relevancy of military leadership, and to the effects of military organization and style on the ability to deal with stress were largely attributable to those with combat deployment experience.

between military service status and the the military model.

Qualitative/ Open-ended interviews

In achieving goals, a successful woman must manage her physicality, sexuality, and femininity cleverly to achieve the trust and confidence of her male as well as female colleagues. 
Nazri \& Rudi / International Journal of Business and Management, 3(2) 2019, Pages: 01-15

\begin{tabular}{|c|c|c|c|c|c|}
\hline Articles & $\begin{array}{l}\text { Country } \\
\text { Settings }\end{array}$ & $\begin{array}{l}\text { Respondent } \\
\text { Sample Size }\end{array}$ & Instrument & Design and Method & Findings \\
\hline [28] & $\begin{array}{c}\text { Norway } \\
\& \\
\text { Sweden }\end{array}$ & $\begin{array}{l}50 \text { Norwegian cadets, } \\
34 \text { Norwegian military officers, } 317 \\
\text { Swedish cadets, and } 190 \text { Swedish } \\
\text { military officers }\end{array}$ & $\begin{array}{l}\text { Data were gathered using a questionnaire } \\
\text { which included two open-ended questions } \\
\text { on aspects which contribute to swift trust } \\
\text { (and lack thereof) towards leaders, as well } \\
\text { as Likert-scale questions on temporary } \\
\text { group characteristics, and a personality } \\
\text { inventory. }\end{array}$ & $\begin{array}{l}\text { Quantitative/ Clustering Analysis and } \\
\text { Correlations }\end{array}$ & $\begin{array}{l}\text { A qualitative clustering analysis of the open-ended responses } \\
\text { yielded a hierarchical model of aspects which contribute to swift } \\
\text { trust (or the lack thereof) with the following two superior categories: } \\
\text { individual-related characteristics such as emotional stability and } \\
\text { relationship-related characteristics such as encourage involvement } \\
\text { and creativity. The latter superior category covaried most strongly } \\
\text { with ratings of the groups' performance }\end{array}$ \\
\hline [29] & Norway & $\begin{array}{l}21 \text { cadets from the Norwegian Air } \\
\text { Force Academy }\end{array}$ & Case study & $\begin{array}{l}\text { Qualitative/ Interview reflected on their } \\
\text { decision-making processes and explored } \\
\text { their reasons for making their decision. } \\
\text { Finally, the decision was executed by the } \\
\text { cadets on whether to jump into the icy } \\
\text { water or not. }\end{array}$ & $\begin{array}{l}\text { The results from "the water jump" exercise showed that most of the } \\
\text { cadets jumped, indicating that they preferred physical } \\
\text { inconvenience over social inconvenience, and that officers are } \\
\text { highly influenced by their group and the military organization. }\end{array}$ \\
\hline
\end{tabular}


Nazri \& Rudi / International Journal of Business and Management, 3(2) 2019, Pages: 01-15

Respondents for the articles varied. They were clustered into seven main groups: commissioned officers, non-commissioned officers, soldiers/crew/subordinates, officer cadets/officer candidates/trainees, military subject matter experts (SMEs), military veterans and other sources (comprised of military documents, leader service records, and military literature).

Commissioned officers and officer cadets/officer candidates/officer trainees were found to be the most preferable respondents followed by SNCOs, soldiers/crew/subordinates and secondary history literature. Additionally, only one article addressed higher-ranking military officers with the ranks of Colonel and Brigadier General. Two articles involved leader biographies, while one article addressed issues related to gender studies involving female respondents.

Notably, studies on military leadership are diverse regarding respondents; however, officers or 'officers to be' were the main concentration as they are the principal ranks that play crucial roles in leading or who are systematically trained to lead. Female respondents within military leadership contexts were found to be inferior, even when compared to military veterans.

\section{Military Leadership}

The review resulted in 105 codes or sub-themes, which consequently epitomised four main themes. The four main themes are leader attributes with 71 sub-themes, adverse situations and environments with 16 sub-themes, leadership development with 11 sub-themes and leadership guiding principles with seven sub-themes.

\section{Leaders' Traits and Attributes}

The literature review revealed that all articles operationalized optimistic military leader attributes in explaining military leadership. More than 70 positive military leadership attributes were discussed, empirically evaluated or assessed. Hence, leader attributes undeniably comprised a theme of the most recent military leadership research. The list of leaders' traits and attributes is presented in Table 3.

The review managed to accumulate ten essential military leaders' traits and attributes that recurred more than two times within all the articles. There were four articles that articulated military experience as important military leader traits and attributes.

Table 3

List of leaders' traits and attributes

\begin{tabular}{|c|c|c|}
\hline & Articles & Leaders' traits \& attributes \\
\hline 1. & {$[15]$} & $\begin{array}{l}\text { Inhibited quality, leadership ability, self- } \\
\text { confidence }\end{array}$ \\
\hline 2. & [16] & $\begin{array}{l}\text { Adaptability, openness, emotional stability, inner } \\
\text { morals, intelligence, will-power/energy, well- } \\
\text { prepared/well-trained, competent, can "read the } \\
\text { situation" }\end{array}$ \\
\hline 3. & [17] & Sense of oneness, job satisfaction \\
\hline 4. & [4] & $\begin{array}{l}\text { Army experience, confidence, ability to make } \\
\text { decisions, leadership quality }\end{array}$ \\
\hline 5. & [18] & Expert knowledge \\
\hline 6. & [19] & $\begin{array}{l}\text { Make independent decision fast, loyalty, } \\
\text { acceptance, creativity, self-sacrifice, } \\
\text { assertiveness, empathy, engagement }\end{array}$ \\
\hline 7. & {$[20]$} & $\begin{array}{l}\text { Conventional wisdom, strategic thinking, clear } \\
\text { expression, courageous }\end{array}$ \\
\hline 8. & {$[21]$} & Skills, abilities \\
\hline 9. & {$[22]$} & $\begin{array}{l}\text { Military leadership competencies, leading by } \\
\text { example, walk-the-talk, intercultural, leader } \\
\text { practices, leader-follower interactions, } \\
\text { intercultural, sensory knowledge, experiences }\end{array}$ \\
\hline 10. & [23] & $\begin{array}{l}\text { Material management, pride of ownership, } \\
\text { "thing-ness of leadership" }\end{array}$ \\
\hline 11. & [24] & $\begin{array}{l}\text { Effective communication, leader skill and } \\
\text { abilities, leader's cognitive skill, intelligence, } \\
\text { expertise, creativity, trust }\end{array}$ \\
\hline 12. & {$[25]$} & Flexible, adaptable, hardiness, resilient \\
\hline 13. & {$[26]$} & Military experience \\
\hline 14. & [27] & $\begin{array}{l}\text { Equivalency, physical and social constraint, trust, } \\
\text { confidence, professional }\end{array}$ \\
\hline 15. & {$[28]$} & $\begin{array}{l}\text { Personality (openness, agreeableness, emotional } \\
\text { stability, extraversion, conscientiousness), swift } \\
\text { trust (DV), encourage involvement, desirable } \\
\text { competences, experience, integrity }\end{array}$ \\
\hline 16. & [29] & Decision making \\
\hline
\end{tabular}

It was argued that experienced military leaders appeared to be more effective in challenging and critical situations [22]. Consequently, experience is one of the desired competences in explaining swift trust towards leadership in military settings [28]. Participative decision making and encouragement of initiative, especially at lower levels, obviously differentiate police officers with military experience from normal police officers [26]. Similarly, military service experienced by veterans during their service has a long lasting positive impact on their leadership abilities in non-military professional careers [4]. 
Three articles examined trust as a crucial military leadership attribute in one way or another. In a study on female US Marines, women leaders suggested that the trust and confidence of their subordinates is successfully achieved if they manage their physicality, sexuality and femininity adeptly [27]. Another study indicated that, while trust between leaders and followers is one of the important antecedents in collectivistic leadership, in the case of General George C. Marshall, trust was found to be an inferior antecedent compared to 'voice' in driving the relationship [24]. On the other hand, swift trust is crucial for a military leader and was found to be one of the determinant factors in the outcomes of group leading performance within the contexts of Norway's and Sweden's militaries [28].

Leaders' confidence became an important attribute, as well, in various contexts within military leadership studies. Three articles exhibited such claims. High confidence in solving problems effectively, especially in stressful situations, was found to be the outcome of a hardy leader [25]. Another study suggested that military veterans have higher confidence levels in leading others [4], while the lack of self-confidence was opposite to an effective leader in military settings [27].

Leaders' adaptability was also of central interest in military leadership studies. Two articles dealt with military leaders' adaptability. The adaptability of an individual leader effectively influences his/her actions in unexpected events [16]. Adaptability is achieved through several individual attributes: openness, emotional stability, an inner moral compass, intelligence, will/energy, skills and experience, prepared/trained, competence and the ability to "read the situation." Another study claimed that military leaders deal with rapidly changing situations in their duties, thus they must be flexible and adaptable enough in responding to such rapid changes [25]. The study also suggested that adaptability is developed through a promising psychological hardiness factor.

Leadership ability was emphasised in two articles. More often than not, a study suggested that military leaders overestimated their leadership abilities and rated themselves as above average [15]. Leadership abilities were also linked with several factors and attributes. It was indicated that the ability to make decisions is apparent among military veterans, reflecting a positive attribute possessed during their training in their service [4]. In other studies, leadership ability was explained as an outcome that works closely with skills. In relation to this statement, a more precise explanation described skill and abilities as important themes and a moderator between shared leadership and team performance in dangerous situations [21]. In another remark, leaders' cognitive skill was noted as playing a role in regulating group performance [24].

Two articles expressed military leaders' proficiency in making decisions. It was suggested that leaders in the Navy make independent decisions faster in environments where there is a lack of information within the mission command philosophy [19]. Additionally, military leaders were found to be influenced by their group or there was social influence in the military leader decision making process [29].

Leaders' emotional stability has also been deliberated on in military leadership studies. There are two articles that specifically stated this notion. Leaders' emotional stability was found to be one of the essential attributes in building trust among followers [28]. In another study, the importance of emotional stability combined with what was called an 'inner moral compass' [16] were the factors in actualising leadership effectiveness. Both were explained to have a strong connection with relationship-oriented leadership behaviour. It was elaborated that these two characteristics are the softer side of relationship-oriented leadership.

Intelligence was also a key attribute in military leadership studies. Two articles specifically acknowledged the concept. One study articulated the importance of intelligence within military leadership by clarifying that intelligent leaders would see new opportunities and options directing them to more appropriate decisions based on situations [16]. Another study suggested that greater leadership performance is achieved through leaders' intelligence combined with cognitive skills and expertise [24].

Competency is another attribute that explains military leadership. Two articles articulated the notion. A study suggested that desired competence is acknowledged as one of the important developmental leadership models in military contexts [28]. Another study explained that military leadership may be guided by a developed, evolved and periodically reviewed competency framework within an organisation [22]. This framework would help not only to evaluate but to improve military leaders' skills, knowledge and ability. 
Nazri \& Rudi / International Journal of Business and Management, 3(2) 2019, Pages: 01-15

There were also other focal attributes and traits uniquely found in one article but not in others. All these attributes and traits were categorised into various multi-traits and models which can be explained, defined and synthesised interchangeably based on the list in Table 3.

\section{Adverse Situations and Environments}

Military leadership studies have also studied various adverse situations and environments. The review revealed that 11 articles expounded fifteen adverse and challenging situations and environments in which military leadership has operated. These are highlighted in Table 4.

\section{Table 4}

List of adverse situations and environments

\begin{tabular}{ll}
\hline \multicolumn{1}{c}{$\begin{array}{c}\text { Situations and } \\
\text { Environments }\end{array}$} & \multicolumn{1}{c}{ Articles } \\
\hline 1. Changing and Dynamic & {$[16,21,22,24,25]$} \\
2. Risky & {$[16,17]$} \\
3. Uncertain and Complex & {$[19,21,24-26,29]$} \\
4. Dangerous & {$[19,21,22,25]$} \\
5. Stressful & {$[22,25,27-29]$} \\
6. Novel & {$[24,25]$} \\
7. Critical & {$[19,25-27]$} \\
8. Hyperphysical & {$[27,29]$} \\
9. Others & $\begin{array}{l}\text { Security, operational, predictable } \\
\text { environment [25]; combat zone [26]; } \\
\text { situational awareness } \\
\text { competitive [19]; double-edged- } \\
\text { sword environment [17] }\end{array}$ \\
\hline
\end{tabular}

In universal settings, leaders were envisaged to have the ability to manage challenging and adverse situations. Nevertheless, there are several contexts that have been highlighted that are uniquely associated with military contexts such as, dangerous, hyperphysical, combat zone, situational awareness and security environments.

\section{Leadership Development}

The review exposed the significance of leadership development within the military leadership studies. Seven articles asserted leadership development as being in line with their studies.
Studies indicated that military professionals believe that effective leaders are the outcome of undergoing military leadership development programs. Hence, leadership development has always been a core element within military organisations [15]. Another study argued that military leaders are trained and developed to lead effectively in pre-defined challenging scenarios [16]. In military organisations, leadership development has consistently been linked with personal development, career development and individual development [17].

According to another study, military veterans concurred that military development programs that they underwent throughout their service had a positive influence and impact on them after they retired [4]. A similar study utilised several leadership development processes such as Army leader development, leadership development, and progressive leadership development programs, training and development, military leader development studies, soldiers' development, selfdevelopment, Army training, self-development, leader development models, and the Army leader development domain and Army doctrine.

Other study proposed that military leadership development programs are suggested to emphasise 'action' functions rather than focussing on knowledge alone [18]. Articulating leadership philosophy in mission command suggested that leadership is deviated when uncertainty escalates. Hence, future team development must emphasise work on "lack of information" challenges [19]. One of the studies conducted on an officer cadet leadership development program suggested that physical inconvenience is preferred by officer cadets over social inconvenience and that indicated officers are highly inspired by their group and organisation [29].

\section{Policy, Guiding Principles and Standards}

The review revealed that military leadership is bound with policy, guiding principles and standards. Several sub-themes were categorised under this main theme, namely mission, Army doctrine, military philosophy, military core values and core principles. Twelve out of 16 articles stated 'mission' as the foremost reference to the task of leading in military settings. Correspondingly, the review managed to establish two important directions where mission is exclusively vital to military leadership. 


\section{Nazri \& Rudi / International Journal of Business and Management, 3(2) 2019, Pages: 01-15}

Firstly, a mission is a regulatory order and direction for military leaders to exercise leadership. Articles affirming this concept are shown in Table 5.

\section{Table 5}

Mission is a regulatory order and direction for military leadership

\begin{tabular}{|c|c|}
\hline Articles & Testimonial \\
\hline \multirow[t]{2}{*}{ [4] } & $\begin{array}{l}\text { The Army has always emphasise leaders to have the } \\
\text { ability to operate in complex, difficult and stressful } \\
\text { mission. }\end{array}$ \\
\hline & $\begin{array}{l}\text { Consistently, military leaders are holding the } \\
\text { responsibility to guide their unit's missions. }\end{array}$ \\
\hline$[15]$ & $\begin{array}{l}\text { Citing the definition of military leadership from U.S. } \\
\text { Army doctrine, mission success is achieved through } \\
\text { leadership process. }\end{array}$ \\
\hline [16] & $\begin{array}{l}\text { The process of decision making at which mission } \\
\text { statement and its analysis are the essentialities to be } \\
\text { considered by a military leader }\end{array}$ \\
\hline [19] & $\begin{array}{l}\text { Mission command is a philosophy that was pre-designed } \\
\text { to guide leader to exercise its leadership function } \\
\text { effectively in the indefinite situation }\end{array}$ \\
\hline$[21]$ & $\begin{array}{l}\text { Military leader must have the ability to influence their } \\
\text { group members to complete their mission efficiently }\end{array}$ \\
\hline$[24]$ & $\begin{array}{l}\text { Having a clear mission may ensure a successful } \\
\text { collectivistic military action }\end{array}$ \\
\hline$[25]$ & $\begin{array}{l}\text { Military leaders' ability to be adaptable and flexible when } \\
\text { leading a complex mission environment that are very } \\
\text { uncertain is always the successful determinant factors }\end{array}$ \\
\hline$[26]$ & $\begin{array}{l}\text { Military leaders at all level exercise their leadership in a } \\
\text { coordinated and cooperative way to accomplish the same } \\
\text { mission }\end{array}$ \\
\hline$[28]$ & $\begin{array}{l}\text { Registering various tasks highlighted by respondents } \\
\text { encompasses of peacekeeping mission, an assault and } \\
\text { educating trainees in military context. }\end{array}$ \\
\hline [29] & $\begin{array}{l}\text { Military leader usually conduct a briefing on mission and } \\
\text { other related issues to the team members well before } \\
\text { carrying-out their operation. This is the practise and being } \\
\text { emphasised in training. }\end{array}$ \\
\hline
\end{tabular}

Secondly, military leaders are organisationally structured based on their mission. An article made known that military appointments such as Chief-ofStaff are also made based on certain mission criteria [17]. Additionally, the article clearly stressed that a leadership position is meant to facilitate the achievement of unit missions. Accordingly, the integration of mission and organisational structure may play a role in determining leadership ability [27].

Military doctrines were also found to be one of the guiding principles and standards in military leadership. Two articles make statements about doctrines in the form of mission and strategy, as well as Army doctrine as a more specific preference.
Military and strategic doctrines are the ones which positively influence a military system, particularly in exercising leadership [26]. Army doctrines specify and provide guidance for leader development programs in the Army [4]. In another article, military core values, traits, and principles embraced by subordinates play an important role in ensuring leadership functions effectively regardless of leaders' gender [27]. Additionally, from the same perspective, military leadership is also influenced by group members' input and leadership principles $[26,27]$.

\section{DISCUSSION}

The review provides a qualitative analysis on recent research studies on military leadership from the last 10 years. The rigorous reviewing process from the two databases resulted in the selection of 16 related articles, and the result signifies the scarcity of military leadership studies published within the time span. It is important to stress that the analysis only covers published works and therefore, unpublished studies were deliberately excluded. Hence, one of the disadvantages is the review was unable to trace and report inconsistent or non-significant findings of other related studies on military leadership. Future reviews may enrich and widen the review by considering the published and unpublished research, and in addition, consider studies from other sources or databases, as well.

Despite the discrepancies, the review has managed to highlight numerous important findings and methodology issues that could be considered by future researchers to facilitate their endeavours in military leadership studies. Within the scope of the review and qualitative synthesis, four main themes appeared to comprise the substance of the recent studies on military leadership: leaders' attributes, adverse situations and environments, leadership development and guiding principles.

The review managed to highlight that leaders' traits and attributes have always been the central issues of discussion and analysis in military leadership studies. Military experience was found to be the most denoted attribute in the last ten years of studies, corresponding with trust, confidence, adaptability, personal ability, decisiveness, emotional stability, intelligence, and leadership competency. Other leaders' attributes that the review managed to qualitatively synthesise are self-confidence, positive personality traits, loyalty, self-sacrifice, assertiveness, empathy, engagement, conventional 


\section{Nazri \& Rudi / International Journal of Business and Management, 3(2) 2019, Pages: 01-15}

wisdom, strategic thinking, courage, sensory knowledge, cognitive skill, creative, integrity, adaptability and hardiness. It is apparent that military leaders are not only expected to possess positive traits and attributes but must translate them into various abilities to lead effectively.

The analysis of leader traits and attributes is one of the earliest approaches in explaining the leadership concept [30]. The approach has a close relation to the 'great man theory', which in recent years, has been disparaged in many disputes amongst leadership scholars [31]. However, leader traits and attributes were found to still be important variables in the current military leadership studies. The set of articles explained these significances in the form of multi-trait taxonomies and models. The review has also revealed that leaders' attributes and traits within all the articles were claimed to be inherit and some developed and gained through military trainings and working experiences. Correspondingly, leadership development is also an important theme revealed from this review. In this respect, manifestly, military leadership is properly developed and fixed via special training and enriched with real or nearly real live experience. Furthermore, leadership traits, attributes and achievements are consistently linked with the military personal and career development of leaders. Consequently, many of these articles acknowledged and recognised that these traits and attributes persist even after military leaders retire from their service.

The review has also managed to illuminate the principal contexts or settings of military leadership studies. There are more than eight main types of adverse situation and environment in which military leadership operates: (1) changing and dynamic; (2) risky; (3) uncertain and complex; (4) dangerous; (5) stressful; (6) novel; (7) critical, and (8) hyperphysical. Specific exclusive types of situation and environment were also expressed within this review: security, operational situation, and predictable environments; combat zones; situational awareness; competitive, and double-edged-sword environments. Explicitly, military organisation is typically linked with adverse environments and situations. Notably, situations and environments were important variables in general leadership studies as maintained by the contingency theory of leadership. The theory argues that leadership is consistently contingent upon situations; as the situation changes, leadership also changes [32-34]. Arguably, with the present peaceful geostrategic and geopolitical landscape, military leaders are also expected to perform their duties effectively in peaceful settings. In this case, the versatility of military leaders in balancing their leadership quality during adverse conditions vis-a-vis favourable situations when required is considered more challenging.

Policy and guiding principles were another remarkable theme rendered in the review. Military leaders are strictly guided by rules and regulations in performing their leadership tasks. A mission was found to be the direction given to military leaders. Moreover, military rank structure is closely linked with the mission given. Additionally, military doctrines are also realised as reference for military leaders besides other principles and leadership philosophy. While most articles declared that such guidance is important, empirical studies addressing those as limitations and constraints in exercising leadership have yet to be substantiated.

In order to advance the review of military leadership, the evaluation of the appropriate factors and peculiarities of military leadership should be established. The approach is based on the association of military leadership with the general leadership practises that have been obtained from this review.

Henceforth, there are four important propositions that the review managed to achieve. First, military leadership emphasises leaders' attributes and traits. Therefore, leaders' in the military are carefully selected from the general public based on predefined requirements, which incorporate the exhibition of positive attributes and traits. Selected persons will undergo the development process to qualify them as military leaders with a specific aim and via a systematic scheme. Through the development process, personal leadership within individuals is exploited, cultivated, developed and improved to comply with military standards. Their leadership performance will be continuously evaluated throughout their service. Hence, fundamental positive leadership attributes and traits are the essence of selection. These attributes and traits are then consistently shaped and developed progressively through additional trainings and working experiences. All of the processes are conducted systematically.

Secondly, military leadership is a responsibility to perform effectively in any military environment, which are mostly challenging (extreme environments and situations). Therefore, the development process of a leader is designed to be tough and to replicate the extreme environments and 
Nazri \& Rudi / International Journal of Business and Management, 3(2) 2019, Pages: 01-15

situations related to what a leader will be facing in line with military standards and the mission of the organisation.

Thirdly, military leadership is structurally designed through several definite expectancies shaped by situation and environment. Hence, leaders are properly assigned to carry out their effective responsibilities within the authority given. Fourthly, the military leadership is developed and expected to perform and exercise leadership to achieve certain objectives based on guidelines, principles and standards. Confined to military settings, objectives are pre-defined in the form of the mission. Leadership guidelines and principles are stipulated in doctrines, guiding principles, philosophy and distinguished military core values. Nevertheless, leaders' positive traits and attributes will allow leaders to exercise their leadership in altering those guidelines and principles accordingly. Based on such premises, the review managed to develop a proposed framework, which illustrates a hypothetical structure of military leadership elements based on studies from the current time period. This is presented in Figure 2. The framework comprises the complex interaction of leaders' traits and attributes, critical influential situations and environments, and other significant elements in military domains.

\section{FUTURE DIRECTION}

The review, based on the findings and analysis on military leadership, sought to examine the current studies and provide directions for future research. The review managed to reflect several paths for future military leadership research. As a start, the scarcity of research on military leadership studies in the last ten years is very apparent. This is followed by the absence of studies from other countries or continents, especially from Asia and Africa. Henceforth, future research on military leadership from other continents and countries would open up a new leadership concept frontier and therefore enrich and enhance the paradigm of global military leadership studies.

Mixed methods research approaches were found to be rare (only one article), whereas qualitative and quantitative methods were usually the chosen approaches. It is important for future research to consider mixed method approaches as mixed methods have been found to be constructive methods in integrating and complementing the strengths and weaknesses of qualitative and quantitative methods [35]. Additionally, mixed method approaches may enrich the research paradigm as some questions cannot be answered through either qualitative or quantitative methods but through both methods [36].

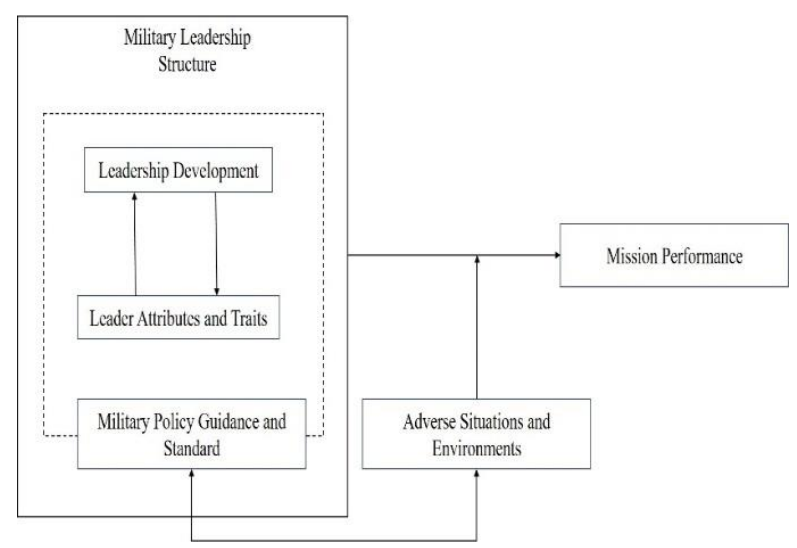

Figure 2. Proposed military leadership framework

Although types of respondents of the research varied across every level, studies on higher or management levels were found to still be deficient. Leaders at the higher level would provide better intuition and discernment on certain issues within military leadership studies. Correspondingly, gender studies were also found to be another area that still offers much to explore in military leadership.

While leaders' traits and attributes are contemplated as old and past concepts of leadership, they are still widely utilised in the current military context. The dynamism of such concepts prevails through multitrait and multi-model approaches. In this respect, many leadership scholars acknowledge the belief that leaders are different from non-leaders as far as attributes and traits are concerned [37]. Likewise, this review is consistent with what is being promulgated on the leader trait paradigm as an important and promising area of future leadership research [38]. Hence, the paradigm of military leaders' traits and attributes is still crucial in military settings for the future. Future researchers are advised to have a more holistic grasp of military leader trait and attribute understanding rather than being constrained and limited by the current status quo. With regard to this preview, it is proposed that more research should address multi-trait and multi-model approaches in their studies.

In association with traits and attributes, leaders' development is evidenced to be of cardinal importance in the military. In due course, it is apparent that leaders in military organisations are properly selected from the general public with 
Nazri \& Rudi / International Journal of Business and Management, 3(2) 2019, Pages: 01-15

specific standard military criteria. Many leadership scholars such as Robert J. Sternberg have acknowledged that individual leaders possess certain giftedness that makes them different from others or from followers [39]. Sternberg articulates that this giftedness can be developed and improved via special training programs or occurrences in life. In the military, training is one of the vital methods to realise military leadership development. Realism provided in trainings portrays actual situations or nearly real situations, eventually equipping and developing leaders with required traits and attributes. Hence, continuous review of effective training schemes and methodology has been found to be another field that is still widely open for future research.

Military leadership has also been confined to certain guidance, doctrines, philosophy, principles and standards, which are revised and produced regularly. Therefore, future research on those may provide crucial findings and results to improve and regulate the content and effective implementation of each reference and guide.

\section{CONCLUSION}

The review has managed to articulate military leadership from current research. Four important themes have been determined: (1) leader traits and attributes; (2) leadership development; (3) adverse situations and environments; and (4) policy, guiding principles and standards. It was found that military leadership research, despite the eminent and powerful historical facts about previous leaders, is still reflected as inferior in the research field. Hence, the review pointed out several recommendations for future research endeavours. Primarily, leader traits and attributes were realised as still being a promising area for future research. This statement may arouse new interest in trait theory at the next level with new insight, new paradigms and approaches. Consequently, the outcome would practically improve military leadership development programs, another subject area, as per now, of perpetual importance to the military.

\section{REFERENCES}

[1] Bass, B.M, 1990. Bass \& Stogdill's Handbook of Leadership - Theory, Research and Managerial Applications. Third Edition. London: The Free Press.

[2] Yukl, G, 2002. Leadership in Organisations. $5^{\text {th }}$ Edition. Pearson Education Limited.

[3] Northouse, P.G, 2016. Leadership: Theory and
Practice. $7^{\text {th }}$ Edition. SAGE Publications Inc.

[4] Kirchner, M.J, 2018. Veteran As Leader: The Lived Experience with U.S Army Leader Development. Human Resource Development Quarterly, 29(2): 67-85.

[5] Taylor, R.L., Rosenbach, W.E., Rosenbach, E.B., Military Leadership: In Pursuit of Excellence. 2009. $6^{\text {th }}$ Edition, Westview Press.

[6] McKenna, A., 2011. The 100 Most Influential World Leaders of All Time. $1^{\text {st }}$ Edition. New York: Britannica Educational Publishing.

[7] Roberts, P., 2015. Eleven Short Articles in Spencer C. Tucker, ed., 500 Great Military Leaders. Vol 2, Santa Barbara, California.

[8] Reiter, D. and Wagstaff, W.A., 2018. Leadership and Miliary Effectiveness. Foreign Policy Analysis, 14(4): 490-511.

[9] Regan, G,. 2000. Great Military Blunder. Macmillan Publishers Ltd.

[10] Kark, R., Karazi-Presler, T. and Tubi, S., 2016. Paradox and Challenges in Military Leadership - Leadership Lessons from Compelling Contexts. Emerald Group Publishing Limited.

[11] Osborn, R.N., and Hunt, J.G. 2007. Leadership and the Choice of Order: Complexity and Hierarchical Perspectives Near the Edge of Chaos, Leadership Quarterly, 18(4): 319-340.

[12] Xiao, Y., and Watson, M. 2019. Guiding on Conducting a Systematic Literature Review. Journal of Planning Education and Research, 39(1): 1-20.

[13] Moher, D. 2015. Preferred Reporting Items for Systematic Review and Meta-analysis Protocols (PRISMA-P) 2015 Statement, Systematic Reviews Journal, 4(1): 1-9.

[14] Chadegani, A.A., Salehi, H., Yunus, M., Farhadi, H., and Fooladi, M. 2017. A Comparison Between Two Main Academic Literature Collection: Web of Science and Scopus Databases, 9(5): 18-21.

[15] Foster, C.A., Clarke, J. A. and Packard, G.A. 2018. Can I See the Real Me? Leadership Ability and the Better-Than-Average Effect. Military Psychology, 30(5): 390-397.

[16] Hyllengren, P. 2017. Military Leaders' Adaptability in Unexpected Situations. Military Psychology, 29(4): 245-259.

[17] Alvinius, A., Johansson, E., and Larsson, G. 2017. Job Satisfaction as a Form of Organisational Commitment at the Military Strategic Level: A Grounded Theory Study. International Journal of Organisational Analysis, 25(2): 312-326.

[18] Thomas, C.H. and Hirschfeld, R.R. 2015. Knowing is Half the Battle: Interdependent Effects of Knowledge and Action on Leader Emergence. Leadership Organisation Development Journal, 36(5): 512-526.

[19] Krabberød, T. 2014. Task Uncertainty and Mission Command in a Naval Context. Small Group Research Journal, 45(9): 416-434.

[20] Goethals, G.R. 2008. Imagining Ulysses S. Grant: Sifting Through the Shifting Sands of 
Conventional Wisdom. Leadership Quarterly, 19(4):488-500.

[21] Ramthun, A.J. and Matkin, J.S. 2014. Leading Dangerously: A Case Study of Military Teams and Shared Leadership in Dangerous Environments. Journal of Leadership and Organizational Studies, 21(3): 244-256.

[22] Fisher, K., and Robbins, C.R. 2015. Embodied leadership: Moving from Leader Competencies to Leaderful practices. Leadership, 11(3): 282299.

[23] Hawkins, B. 2015. Ship-shape: Materializing Leadership in the British Royal Navy. Human Relations, 68(6): 951-971.

[24] Friedrich, T.L., Vessey, W.B., Schuelke, M.J.,, Mumford, M.D., Yammarino, F.J., and Ruark, G.A. 2014. Collectivistic Leadership and George C. Marshall: A Historiometric Analysis of Career Events. Leadership Quarterly, 25(3): 449-467.

[25] Bartone, P.T., Kelly, D.R., and Matthews, M.D. 2013. Psychological Hardiness Predicts Adaptability in Military Leaders: A Prospective Study. International Journal of Selection and Assessment, 21(2): 200-210.

[26] Shernock, S. 2016. Conflict and Compatibility Perspectives of Police Officers with and without Military Service on the Military Model of Policing. Policing: An International Journal of Police Strategies \& Management, 39(4): 740755.

[27] Brownson, C. 2014. The Battle for Equivalency: Female US Marines Discuss Sexuality, Physical Fitness, and Military Leadership. Armed Forces Society. 40(4): 765-788.

[28] Hyllengren, P., Larsson, G., Fors, M., Sjöberg, M., Eid, J., and Olsen, O.K. 2011. Swift Trust in Leaders in Temporary Military Groups. Team Performance Management, 17(7): 354-368.

[29] Firing, K., Karlsdottir, R., and Laberg, J.C. 2009. Social Influence in Military Leadership Training, 30(8): 709-721.

[30] Zaccaro, S., Kemp, C., and Bader, P. 2004. Leader Traits and Attributes. In: Antonakis, J., Cianciolo, A.T., and Sternberg, J.R, (editors). The Nature of Leadership. Thousand Oaks, CA: Sage.

[31] Yukl, G, 2010. Leadership in Organisations. $7^{\text {th }}$ Edition. Pearson Education Limited.

[32] Verkerk, P. 1990. Fiedler's Contingency Model of Leadership Effectiveness: Background and Recent Developments. Eindhoven University of Technology Journal.

[33] Geier, M.T. 2016. Leadership in Extreme Contexts: Transformational Leadership, Performance Beyond Expectations? Journal of Leadership and Organisational Study, 23(3):234-47.

[34] Hannah, S.T., Avolio, B.J., Luthans, F., and Harms, P.D. 2008. Leadership Efficacy: Review and Future Directions. Leadership Quarterly, 19(6):669-92.

[35] Yinn, R.K. 2011. Qualitative Research from Start to Finish. New York: Guilford Press, Guilford
Publications, Inc.

[36] Creswell, J.W. 2013. Research Design: Qualitative, Quantitative, and Mixed Methods Approaches. 4th Edition. Sage Publications, Inc. Washington DC.

[37] Zaccaro, S. 2007. Trait-based Perspectives of Leadership. American Psychologist, 62(1):6-16.

[38] Judge, T.A., Piccolo, R.F., and Kosalka, T. 2009. The Bright and Dark Sides of Leader Traits: A Review and Theoretical Extension of the Leader Trait Paradigm. Leadership Quarterly, 20(6):855-75.

[39] Sternberg, R.J. 2003. WICS: A Model of Giftedness in Leadership. High Abilities Study, 14(2):37-44 